\title{
The Role of Competency: Comparing Social Intelligence and Teaching and Learning Performance among Academics Staffs' in Malaysian Private Higher Education Institutions
}

Janitha Kularajasingam, Anusuiya Subramaniam, Devinder Kaur

To Link this Article: http://dx.doi.org/10.6007/IJARBSS/v12-i2/12258

DOI:10.6007/IJARBSS/v12-i2/12258

Received: 08 December 2021, Revised: 11 January 2022, Accepted: 28 January 2022

Published Online: 16 February 2022

In-Text Citation: (Kularajasingam et al., 2022)

To Cite this Article: Kularajasingam, J., Subramaniam, A., \& Kaur, D. (2022). The Role of Competency: Comparing Social Intelligence and Teaching and Learning Performance among Academics Staffs' in Malaysian Private Higher Education Institutions. International Journal of Academic Research in Business and Social Sciences, 12(2), 310-321.

\section{Copyright: (c) 2022 The Author(s)}

Published by Human Resource Management Academic Research Society (www.hrmars.com)

This article is published under the Creative Commons Attribution (CC BY 4.0) license. Anyone may reproduce, distribute, translate and create derivative works of this article (for both commercial and non0-commercial purposes), subject to full attribution to the original publication and authors. The full terms of this license may be seen at: http://creativecommons.org/licences/by/4.0/legalcode

\section{Vol. 12, No. 2, 2022, Pg. $310-321$}

Full Terms \& Conditions of access and use can be found at http://hrmars.com/index.php/pages/detail/publication-ethics 


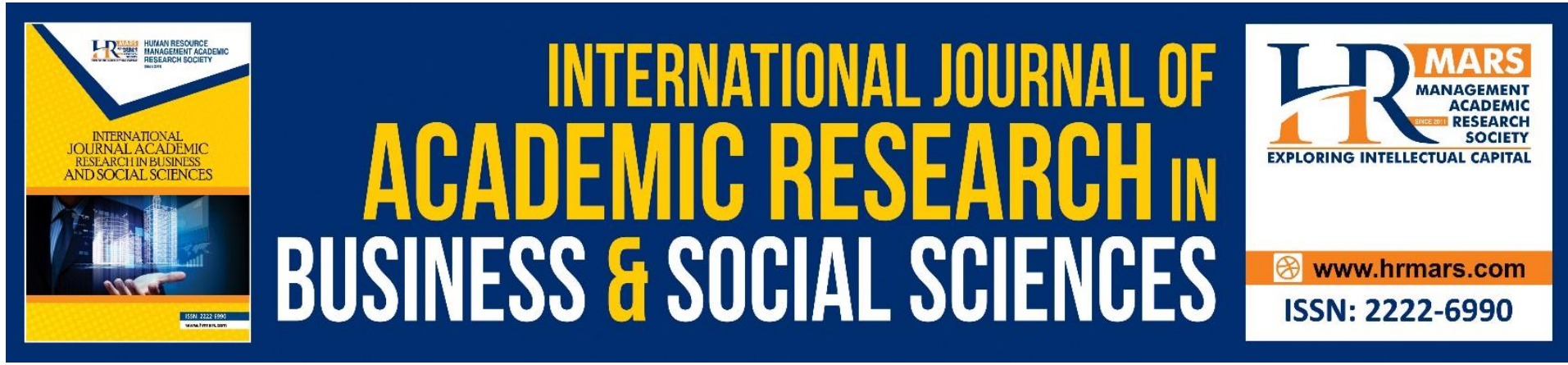

\title{
The Role of Competency: Comparing Social Intelligence and Teaching and Learning Performance among Academics Staffs' in Malaysian Private Higher Education Institutions
}

\author{
Janitha Kularajasingam \\ School of Marketing and Management, Asia Pacific University of Technology and Innovation, \\ 57000 Kuala Lumpur, Malaysia. \\ Email: janitha@apu.edu.my
}

\section{Anusuiya Subramaniam}

School of Business \& Economics, Universiti Putra Malaysia, 43400 Serdang, Selangor, Malaysia.

Email: anusuiya@upm.edu.my

\section{Devinder Kaur}

School of Marketing and Management, Asia Pacific University of Technology and Innovation, 57000 Kuala Lumpur, Malaysia.

Email: devinder.kaur@apu.edu.my

\begin{abstract}
Academic staff's social intelligence plays an important part in increasing their teaching and learning performance owing to their magnitude of competency. However, empirical research that associates both constructs is limited. Thus, this research aspires to scrutinise the influence of social intelligence on teaching and learning performance among academic staff with the moderating effect of competency. A self-administered questionnaire survey was used to collect data from 318 academic staff in the business schools of seven Malaysian private higher education institutions located in Klang Valley. SPSS version 26 were used to analyse data. The findings revealed the following: (1) social intelligence has a significant positive influence on competency, (2) competency has a significant positive influence on teaching and learning performance, (3) social intelligence has a significant positive influence on teaching and learning performance and (4) competency significantly moderates the association between social intelligence and teaching and learning performance. Theoretical and practical implications are discussed.
\end{abstract}

Keywords: Social Intelligence, Competency, Teaching and Learning Performance, Academic Staffs, Private Higher Education Institutions, Malaysia 


\section{Introduction}

An institution's human capital is vital in realising the attainment of its goals and aspirations, with each employee playing a key role in their achievement. Human capital is responsible for accomplishing an organisation's tasks, since employees' performance directly reflects organisational performance. This is similar to the atmosphere in higher education institutions, where the success of a higher education institution and its students is greatly determined by academics' success in performing their duties. Therefore, it is essential for crucial for higher education institutions to attain and foster their human capital towards delivering quality performance in teaching and research, as the existence of qualified and experienced academic staff could be a major selling point to student applicants (Bossu et al., 2019). Towards enhancing the performance of the academics, it is imperative to extensively emphasise their teaching and learning performance, which stresses the improvement of academic staff's expertise and capabilities (Talebi \& Abedini, 2016).

As posited by June et al (2013), teaching and learning performance is grounded in both work-related knowledge as well as the correct completion of work. Teaching and learning performance can be considered an individual's actions that contribute towards their postemployment performance (June et al., 2013). This calls for academic staff to possess the necessary knowledge, skills and attitude that enable them to perform well in higher education institutions. Academics' expertise and performance (in teaching and research) directly contribute to an institution's success in terms of ranking, scholarly output and the satisfaction of stakeholders' expectations (Cheng et al., 2019). Substantial research has been conducted on teaching performance in the higher education institutions sector (Ghasemy et al., 2018). However, limited empirical work has been done specifically on teaching and learning performance in the higher education institutions arena (Zhu et al., 2013).

Social intelligence is referred to as one's attentiveness to the social dynamics around him/her, wherein his/her knowledge about communication techniques help him/her accomplish the goals of an interaction (Nazarpoori, 2017). Meanwhile, competency is acknowledged as the ability to organise, assimilate and pass on knowledge, skills and resources to achieve or exceed one's designated performance in job tasks, particularly in a manner that contributes financial and social value to oneself and one's organisation (Brown, George \& Mehaffey-Kultgen, 2018). Extant studies have established that social intelligence is a requisite factor in the development of competency (Janudin, Maelah, Amir \& Abdullah, 2015). Nonetheless, research on academic staff has predominantly emphasised situational work variables, neglecting the influence of personal factors like social intelligence on competency development (Grossman \& Salas, 2011). Consequently, it is imperative to study the link between social intelligence and competency in the context of academic staff.

As posited by prior scholars, individuals with high competency are expected to attain greater work performance as competency enables an individual to carry out a given task effectively (Janudin et al., 2015). Scholars have found that the competency level of academic staff assists in improving their performance (Kaur et al., 2018), implying that competency and teaching and learning performance are highly vital elements of academics' delivery of efficient teaching approaches. Even so, academic staff's performance has generally been linked to only teaching and learning outcomes, while few studies have included competency as a determinant of performance (Kaur et al., 2018).

Social intelligence is known to be an effective tool for problem solving in one's various social tasks and social activities (Nagra, 2014). According to previous researchers, social intelligence represents not only dispositional and intrinsic attributes but is also a trainable 
skill that facilitates desirable social changes via better individual wellbeing (Saxena \& Jain, 2013). Thus, possessing strong social intelligence is crucial for one's success in life (Meijs et al., 2010). Research has also revealed that social intelligence aids academic staff in being empathetic towards others' feelings, motivating others and regulating their own emotions in forming relationships (Nazarpoori, 2017; Saxena \& Jain, 2013). As such, social intelligence can greatly affect the teaching and learning performance of academic staff (Goleman, 2006). However, despite this theoretical evidence, empirical research linking social intelligence to academics' teaching and learning performance is rare.

Academicians' teaching and learning performance is strongly related to their knowledge on work goals as well as their proficiency in achieving the job requirements assigned by higher education institutions (Subramaniam \& Haji Jasmin, 2017). In this regard, academic staff's social intelligence has the potential to improve their teaching and learning performance via their competency level (Bennett, 2015).

A review of studies associated to higher education management shows that the excellence of higher education institutions is extremely dependent on the competencies of their academic staffs (Gandy et al., 2018; Khalid, 2019). However, only few scholars have attempted to examine competency as a moderator that strengthens the effect of social intelligence on teaching and learning performance.

Prior scholarly efforts on teaching and learning performance in the higher education institutions arena have leaned towards conceptual frameworks that are generally not backed by empirical results. It is clear that the teaching and learning performance of academic staff is dependent on social intelligence (Nazarpoori, 2017). This can be further enhanced by the effect of perceived competency (Bennett, 2015). Therefore, this study has significant value as it addresses the gap in the literature pertaining to the lack of research linking social intelligence to teaching and learning performance with the moderation of perceived competency.

\section{Literature Review \\ Social Intelligence and Competency}

The theoretical foundations of competency in the behavioural psychology field precedes its specific terminology. Intelligence and competency are concepts that have typically been used interchangeably though they are, in fact, different (Rose-Krasnor, 1997). Among the distinctions between the two identified in research are the context-specific nature of competency (Deary et al., 2006) and the broader definition of intelligence concepts across settings and contexts (Rose-Krasnor, 1997). While competency seems to vary with learning and enhancement, intelligence has been reported to be inherited and relatively constant over time (Rose-Krasnor, 1997). Nevertheless, intelligence is a key component in the measurement of competency (Rose-Krasnor, 1997).

Earlier findings reveal that academic staff in a higher education institution can perform their job effectively only if they possess the requisite knowledge, skills and attitude (DarlingHammond, Flook, Cook-Harvey, Barron \& Osher, 2019). Consequently, competency is mandatory for them to complete their job tasks in a better manner. Studies have found that social intelligence positively impacts an individual's competency in achieving career success (Eshghi, Arofzad \& Hosaini, 2013). Therefore, it was hypothesised that:

H1: Academic staff's social intelligence level has a positive effect on their competency level 


\section{Competency and Teaching and Learning Performance}

Scholar have established that competency facilitates heightened performance and matches an employee to the most fitting occupation as well as organisation (Shaheen et al., 2019). Good fit has been shown to enhance job satisfaction, job engagement and job performance by pairing a job's requirements to the job holder's competencies (Shaheen et al., 2019).

As mentioned by Eshghi et al (2013), the link between competency and teaching and learning performance is grounded in the competency-based framework, wherein academics' fit and efficacy in their job reflects their behaviours and subsequently, their performance. Hakim (2015) found that academics' competencies (pedagogical, social, personal and professional) significantly influence their teaching performance. Based on this discussion, it was hypothesised that:

H2: Academic staff's competency level has a positive effect on their teaching and learning performance

\section{Social Intelligence and Teaching and Learning Performance}

Social intelligence is considered among the most important and critical fields in the social sciences and humanities (Jahanian, 2010). Social intelligence is vital for today's lifestyle due to life's growing stresses and various complexities (Saxena \& Jain, 2013). Saxena and Jain (2013) reported that social intelligence is learnable, fosterable and useable as a valuable life aptitude that facilitates the management of one's personal life, social connections and success in various life aspects.

Previous scholars have established that social intelligence positively affects academicians' efficacy in the educational context (Agarwal, 2003), specifically in terms of academic, personal and moral effectiveness. Likewise, Lathesh and Avadhani (2018) stated that social intelligence helps one resolve challenges, enhance performance, boost both individual and organisational success. Relating this to academicians' teaching and learning performance, it was hypothesised that:

H3: Academic staff's social intelligence level has a positive effect on their teaching and learning performance

\section{Competency as a Moderator between Social Intelligence and Teaching and Learning Performance}

Saxena and Jain (2013) claimed that success in life is hardly feasible without the possession of some level of social intelligence. Social intelligence levels grow with an individual's age and experience, given that it is developed via social connections rather than formal training (Mohan et al., 2015). This implies that healthy relationships can be fostered among academic staff if they possess and apply good communication skills. Using such skills, academicians can strive for personal growth and performance improvement so they can improve their higher education institutions' productivity (Nguyen et al., 2016). Moreover, the result of their efforts would enhance their teaching and learning performance when their competency level (for example, knowledge, skills, and attitude) is high, thereby attaining competitive advantage for the higher education institutions. Based on this discussion, it was hypothesised that: 
H4: Competency moderates the positive effect of academic staff's social intelligence level on their teaching and learning performance

\section{Methodology}

\section{Sampling and Data Collection}

This research was conducted in a developing country in Southeast Asia, i.e., Malaysia. Target respondents comprised academic staff from business schools in seven private higher education institutions in Malaysia, specifically in the Klang Valley region. A self-administered survey was developed and distributed via the drop-and-pick method with the aid of each business school's Dean. The respondents were made aware that completing and returning the survey would signify their informed consent to participate in the research. Upon collecting the completed questionnaires from each higher education institution, a total of 318 usable responses were received.

\section{Measurement}

All the survey items were rated on a 5-point Likert scale with indicators from 1 (strongly disagree) to 5 (strongly agree). Social intelligence was assessed via the 21-item Tromso Social Intelligence Scale (Silvera et al., 2001). Sample items were "I can predict other people's behaviour" and "I fit in easily in social situations".

Competency was evaluated with Zhu et al.'s (2013) 30-item scale, which included items like "I love to participate in all kinds of training activities" and "I am willing to spend more time on teaching issues". Teaching and learning performance was assessed as a multidimensional construct. The measure for the Innovative Teaching dimension was adapted from Zhu et al (2013) and had 29 items. The Research and Publication dimension comprised four items by Farh, Werbel and Bedeian (1988) that were also verified by (Md-Sidin et al., 2009). Finally, three items adapted from Ishak et al (2009) were used to measure the Supervision dimension. Examples of items for teaching and learning performance were "I try to use different methods to solve the same teaching problem" for the Innovative Teaching dimension, "Editor for journals" for the Research and Publication dimension, and "Number of project supervision" and "Number of postgraduate supervision" for the Supervision dimension.

\section{Profile of Respondents}

The survey also measured the demographic background of the respondents, specifically their gender, age, ethnicity, work experience, academic qualification, job position, and employment status. Of the 318 private higher education institutions academicians in this research, females (66.4\%) outnumbered males (33.6\%). A majority were aged from 38 to 54 (41.8\%), followed by those aged from 31 to 37 (33.6\%), 24 to 30 (15.4\%), and above 55 (9.1). Most respondents were from the Chinese $(33.6 \%)$ and Indian $(28.6 \%)$ race, while only $11.3 \%$ were Malays. In terms of work experience, an equally large amount had 11 to 15 years (25.8\%) or six to 10 years (25.2\%) of experience, while the remaining had 16 to 20 years (16.4\%), one to five years (15.1\%), more than 20 years $(14.8 \%)$ or less than one year $9(2.8 \%)$ of experience.

Pertaining to their education level, a majority possessed a Master's Degree (61.3\%), while a substantial portion also possessed Doctorate qualifications (30.8\%). Only a minority had a Bachelor's Degree (6.3\%) and DBA (1.6\%). With regard to job position in the organisation, most of the respondents were Lecturers $(63.5 \%)$, while some were Senior 
Lecturers (30.5\%). A small percentage comprised Associate Professors (3.1\%), Professors $(2.2 \%)$, Heads of School (0.3\%) and Deans (0.3\%).

\section{Data Analysis and Results \\ Data Analysis}

The data collected in this research was analysed via the Statistical Package for the Social Sciences (SPSS) version 26.0 software. This analytical approach constituted frequency distribution for the demographic data and analyses of reliability, simple regression, and stepwise moderated regression for the study variables. The reliability analysis results showed that Cronbach's alpha $(\alpha)$ was between 0.724 and 0.956 for the variables. Specifically, the $\alpha$ coefficients were 0.724 for social intelligence, 0.956 for competency, and 0.904 for teaching and learning performance. These findings confirm that the study constructs had satisfactory internal consistency.

\section{Simple Regression Analysis Results}

Simple regression was used to examine the linkages between (1) social intelligence and competency, (2) competency and teaching and learning performance, and (3) social intelligence and teaching and learning performance. As shown in Table 1, social intelligence has a significant positive relationship with competency $(B=0.271, p<0.01)$, competency has a significant positive relationship with teaching and learning performance $(B=0.665, p<$ 0.01 ), and social intelligence has a significant positive relationship with teaching and learning performance $(B=0.387, p<0.01)$. Based on these results, $\mathrm{H} 1, \mathrm{H} 2$ and $\mathrm{H} 3$ were supported.

Table 1 Simple Regression Results

\begin{tabular}{lllll}
\hline Hypothesis tested & $\begin{array}{l}\text { Standardised } \\
\text { estimate }(6)\end{array}$ & $\begin{array}{l}\text { Critical ratio } \\
(t)\end{array}$ & $p$ value & Supported \\
\hline $\begin{array}{l}\text { H1: Social Intelligence } \\
\quad \text { Competency }\end{array}$ & 0.27 & 5.01 & 0.00 & Yes \\
$\begin{array}{l}\text { H2: Competency } \longrightarrow \\
\quad \begin{array}{l}\text { Teaching and Learning } \\
\quad \text { Performance }\end{array}\end{array}$ & 0.67 & 15.84 & 0.00 & Yes \\
$\begin{array}{l}\text { H3: Social Intelligence } \\
\quad \text { Teaching and Learning } \\
\quad \text { Performance }\end{array}$ & 0.39 & 7.47 & 0.00 & Yes \\
\hline
\end{tabular}

\section{Stepwise Moderated Regression Analysis Results}

Following the recommendation of Baron and Kenny (1986), a stepwise moderated regression was performed to examine the moderating effect of competency between social intelligence and teaching and learning performance. As presented in Table 2, the coefficient of determination $\left(R^{2}\right)$ demonstrated a significantly higher value after the inclusion of the interaction term $\left(\Delta R^{2}=0.324, b=0.904, p<0.01\right)$ with the moderator. Therefore, the influence of social intelligence on teaching and learning performance is significantly moderated by competency, as predicted. Hypothesis $\mathrm{H} 4$ was thus supported. 
Table 2 Stepwise Moderated Regression Results

\begin{tabular}{lll}
\hline & \multicolumn{2}{l}{$\begin{array}{l}\text { Dependent Variable:- } \\
\text { Teaching and Learning Performance }\end{array}$} \\
\cline { 2 - 3 } & $\begin{array}{l}\text { Model 1 } \\
\text { (Standard Beta) }\end{array}$ & $\begin{array}{l}\text { Model 2 } \\
\text { (Standard Beta) }\end{array}$ \\
\hline $\begin{array}{ll}\text { Independent Variable } \\
\quad \text { Social Intelligence }\end{array}$ & 0.39 & \\
Interaction Term & & 0.90 \\
$\quad$ Social Intelligence x Competency & & 0.47 \\
\hline $\mathrm{R}^{2}$ & 0.15 & 0.47 \\
Adjusted $\mathrm{R}^{2}$ & 0.15 & 0.32 \\
$\Delta \mathrm{R}^{2}$ & 0.15 & $142.14^{* *}$ \\
$\mathrm{~F}$ Value & $55.82^{* *}$ & \\
\hline$* * p<0.01$ & &
\end{tabular}

\section{Discussion}

This study highlights the crucial role of social intelligence in developing the competency, and subsequently, the teaching and learning performance of academicians in private higher education institutions. Beyond that, the role of competency in strengthening the effect of social intelligence on teaching and learning performance was also explored.

First, the results suggest that academic staff's social intelligence level increases their competency level, which supports previous studies' assertion that one's ability to achieve a higher social standing is linked to better knowledge, skills and attitude (Zhu et al., 2013). That is, academicians' become more confident by attaching social meanings and objectives to their decisions and behaviours, which allows them to demonstrate more job-related knowledge, skills, and attitudes. Thus, academic staff must exert their full efforts in their personal development and performance to portray values that benefit higher education institutions' productivity (Mohan et al., 2015). This would enhance academicians' performance via their improved knowledge, skills, and attitude and consequently, attain competitive advantage for private higher education institutions.

Second, the findings of this study also indicate that academic staff's competency level improves their teaching and learning performance. Consistent with this, Ahadzie, Proverbs, Olomolaiye \& Ankrah (2009) found that competency affects teaching and learning performance by channelling academics' suitable and useful competencies into their behaviours, outcomes, and performance. Likewise, other scholars (Ryan, Emmerling \& Spencer, 2009) have affirmed the validity and efficacy of competency as a determinant of employees' job performance.

Third, the empirical findings show that social intelligence boosts academic staff's teaching and learning performance, validating that social intelligence, which encompasses social information processing, social skills and social awareness, contributes to teaching and learning performance in the form of innovative teaching methods, research and publication output and supervisory tasks. This is in line with Eshghi et al.'s (2013) finding that as educators' social intelligence increases, so does their teaching and learning performance.

Fourth, the result on the moderating role of competency adds to the knowledge on the boundary conditions that strengthen the effect of social intelligence on teaching and learning performance. It suggests that social intelligence has a stronger impact on academics' teaching and learning performance when they have higher degrees of job-related knowledge, 
skills and attitude. Extant research also supports that competency development is critical for academic staff (Nordin, 2021).

Based on these findings, this research offers valuable insights on ways to improve academicians' teaching and learning performance in private higher education institutions. In the current era, higher education institutions have substantially transformed themselves to adapt to dynamic changes in costs, student numbers, globalisation and managerial approaches. The current business environment is further becoming more radical and challenging, making academicians' skill development and talent management a key concern for higher education institutions. Indeed, the higher education sector is heavily dependent on its acceptance of change, its adaptation to change for the improvement of practices, and its creation of competitive advantages. The quality of academic staff is now the main area of attention for higher education institutions, as it is strongly related to the achievement of desired teaching and learning performance. Towards this end, this study offers empirical support for the significant effects of social intelligence and competency on academic staff's delivery of higher quality teaching and learning, which ultimately shapes a more conducive environment for moulding future leaders. Overall, this study posits that academicians should be empowered with the requisite skills that enable them to uphold their professional duties through training and educational opportunities to hone their social intelligence and competency.

\section{Conclusion}

Understanding the determinants of teaching and learning performance has long been an important endeavour of researchers in the fields of industrial-organizational psychology and organizational behaviour, but few have shown interest in non-Western countries. With regards to this theoretical standpoint, the present study has built on the literature on teaching and learning performance in the context of academic staff in Malaysian private higher education institutions. In addition to establishing social intelligence and competency as predictors of teaching and learning performance, the findings also expand the knowledge of the boundary conditions that determine the strength of the association between social intelligence and teaching and learning performance, i.e., competency. As few studies have attempted to link social intelligence and competency to teaching and learning performance, this research fills this gap in the literature, especially pertaining to private higher education institutions. Therefore, the present study may potentially serve as a reference for the Ministry of Higher Education in its efforts to increase academic staff's performance via effective human resource policies that prioritise the development of academics' social intelligence, competencies, and teaching and learning performance.

This research is not without limitations. First, the study's data was cross-sectional, which prevents the assumption of causality between the study variables. Future studies could employ a longitudinal approach to examine this topic. Second, to overcome the limitations of the quantitative method used in this study, in-depth qualitative research via interviews, observations and focus groups would be useful. Third, this study only tested competency as a moderator between social intelligence and teaching and learning performance. As such, researchers in the future could incorporate alternative moderating constructs, such as organisational commitment, job satisfaction and emotional states. 


\section{References}

Agarwal, R. (2003). Social Intelligence and Teacher Effectiveness (Doctoral dissertation). Bundelkhand University, Jhansi, Uttar Pradesh, India. Retrieved from http://hdl.handle.net/10603/10782

Ahadzie, D. K., Proverbs, D. G., Olomolaiye, P.O., \& Ankrah, N. (2009). Towards developing competency-based measures for project managers in mass house building projects in developing countries. Construction Management and Economics, 27(1), 89-102. https://doi.org/10.1080/01446190802621028

Baron, R. M., \& Kenny, D. A. (1986). The moderator-mediator variable distinction in social psychological research: Conceptual, strategic and statistical considerations. Journal of Personality and Social Psychology, 51(6), 1173-1184. https://doi.org/10.1037//00223514.51.6.1173

Bennett, B. (2015). Social intelligence of undergraduates enrolled in traditional vs. distance higher education learning programs. Retrieved from

https://scholarworks.waldenu.edu/cgi/viewcontent.cgi?article=1741\&context=dissert ations

Bossu, C., Brown, N., \& Warren, V. (2019). Career progression and development of professional staff in higher education. In Bossu, C, \& Brown, N. (Eds.). Professional and support staff in higher education. University development and administration (pp. 110). Springer. https://doi.org/10.1007/978-981-10-1607-3_34-3

Brown, L., George, B., \& Mehaffey-Kultgen, C. (2018). The development of a competency model and its implementation in a power utility cooperative: an action research study. Industrial and Commercial Training, 50(3), 123-135. https://doi.org/10.1108/ICT-112017-0087

Cheng, B. L., Cham, T. H., Micheal, D., \& Lee, T. H. (2019). Service Innovation: Building a Sustainable Competitive Advantage in Higher Education. International Journal of Services, Economics and Management, 10(4), 289-309. https://dx.doi.org/10.1504/IJSEM.2019.105014

Darling-Hammond, L., Flook, L., Cook-Harvey, C., Barron, B., \& Osher, D. (2019). Implications for educational practice of the science of learning and development. Applied Developmental Science, 24(2), 1-44. https://doi.org/10.1080/10888691.2018.1537791

Deary, I. J., Spinath, F. M., \& Bates, T. C. (2006). Genetics of intelligence. European Journal of Human Genetics, 14(6), 690-700. https://doi.org/10.1038/sj. ejhg.5201588

Eshghi, P., Arofzad, S., \& Hosaini, T. A. (2013). Relationship between social intelligence with effective influence among physical education expertise in Isfahan Education Organizations. European Journal of Experimental Biology, 3(3), 168-172.

Farh, J. L., Werbel, J. D., \& Bedeian, A. G. (1988). An empirical investigation of self- appraisalbased performance evaluation. Personnel Psychology, 41(1), 141-156.

Gandy, R., Harrison, P., \& Gold, J. (2018). Talent management in higher education: is turnover relevant? European Journal of Training and Development, 42(9), 597610.https://doi.org/10.1108/EJTD-11-2017-0099

Ghasemy, M., Hussin, S., Daud, M. A. K. M., Nor, M. M., Ghavifekr, S., \& Kenayathulla, H. B. (2018). Issues in Malaysian higher education: A quantitative representation of the top five priorities, values, challenges, and solutions from the viewpoints of academic leaders. SAGE Open, 8(1), 215824401875583.

https://doi.org/10.1177\%2F2158244018755839

Goleman, D. (2006). The socially intelligent. Educational leadership, 64(1), 76-81. 
Grossman, R., \& Salas, E. (2011). The transfer of training: what matters. International Journal of Training and Development, 15(2), 103-120. https://doi.org/10.1111/j.14682419.2011.00373.x

Hakim, A. (2015). Contribution of competence teacher (pedagogical, personality, professional competence and social) on the performance of learning. The International Journal of Engineering and Science, 4(2), 1-12.

Ishak, M. I. M., Suhaida, M. S., \& Yuzainee, M. Y. (2009). Performance measurement indicators for academic staff in Malaysia private higher education institutions: A case study in UNITEN. PMA Conference 2009, University of Otago, Dunedin, New Zealand.

Jahanian, R. (2010). Study the relationship between emotional intelligence and conflict management in managers. Journal of Management, 8, 1-8. http://dx.doi.org/10.5267/j.msl.2012.07.015

Janudin, S. E., Maelah, R., Amir, A. M., \& Abdullah, N. L. (2015). Performance measurement system and lecturers' performance: Testing the mediation role of competency in Malaysian research universities. International Business Education Journal, 8(1), 105120. Retrieved from https://ejournal.upsi.edu.my/index.php/IBEJ/article/view/1378

June, S., Yeoh, K., \& Mahmood, R. (2013). Determining the Importance of Competency and Person-Job Fit for the Job Performance of Service SMEs Employees in Malaysia. Asian Social Science, 9(10), 114-123. https://doi.org/10.5539/ass.v9n10p114

Kaur, I., Shri, C., \& Mital, K. (2018). Performance management model for teachers based on emotional intelligence and social media competencies. Journal of Advances in Management Research, 15(4), 414-433.

Khalid, F., (2019). The choreography of talent development in higher education. Higher Education Studies, 9(1), 40-52. http://dx.doi.org/10.5539/hes.v9n1p40

Lathesh, K. R., \& Avadhani, V. D. (2018). A study on social intelligence and its impact on employee performance of insurance sectors in Mysuru City. International Journal of Mechanical Engineering and Technology, 9(1), 530-537.

Md-Sidin, S., Sambasivan, M., \& Muniandy, N. (2009). Impact of psychological ownership on the performance of business school lecturers. Journal of Education for Business, 85(1), 50-56. https://doi.org/10.1080/08832320903217903

Meijs, N., Cillessen, A. H., Scholte, R. H., Segers, E., \& Spijkerman, R. (2010). Social intelligence and academic achievement as predictors of adolescent popularity. Journal of Youth and Adolescence, 39(1), 62-72. https://doi.org/10.1007/s10964-008-9373-9

Mohan, M. D., Muthaly, S., \& Annakis, J. (2015). Talent Culture's Role in Talent Development among Academics: Insights from Malaysian Government Linked Universities. Journal of Contemporary Issues in Business \& Government, 21(1), 46-71.

Nagra, V. (2014). Social intelligence and adjustment of secondary school students. ParipexIndian Journal of Research, 3(4), pp 86-87.

Nazarpoori, A. (2017) A survey of the effect of leader's social intelligence on employee's perception of interpersonal justice: the mediating role of shared leadership. International Journal of Leadership in Education, 20(5), 618-631. https://doi.org/10.1080/13603124.2017.1283063

Nguyen, Q., Klopper, C., \& Smith, C. (2016). Affordances, barriers, and motivations: engagement in research activity by academics at the research-oriented university in Vietnam. Open Review of Educational Research 3(1), 68-84.

https://doi.org/10.1080/23265507.2016.1170627 
Nordin, N. (2021). Leadership Competencies Development Among Academic Staffs: A Preliminary Observation. Malaysian Journal of Social Sciences and Humanities (MJSSH), 6(7), 370-375. https://doi.org/10.47405/mjssh.v6i7.868

Rose-Krasnor, L. (1997). The nature of social competence: A theoretical review. Social Development, 6(1), 111-135. https://doi.org/10.1111/j.1467-9507.1997.tb00097.x

Ryan, G., Emmerling, R. J., \& Spencer, L. M. (2009). Distinguishing high-performing European executives. Journal of Management Development, 28(9), 859-875. https://doi.org/10.1108/02621710910987692

Saxena, S., \& Jain, R. K. (2013). Social intelligence of undergraduate students in relation to their gender and subject stream. IOSR Journal of Research \& Method in Education, 1(1), 1-4.

Shaheen, M., Azam, M. D. S., Soma, M. K., \& Kumar, T. J. M. (2019). A competency framework for contractual workers of the manufacturing sector. Industrial and Commercial Training, 51(3), 152-164. https://doi.org/10.1108/ICT-10-2018-0080

Silvera, D., Martinussen, M., \& Dahl, T.I. (2001). The Troms $\varnothing$ Social Intelligence Scale, a selfreport measure of social intelligence. Scandinavian Journal of Psychology, 42(4), 313319. https://doi.org/10.1111/1467-9450.00242

Subramaniam, A., \& Haji Jasmin, N. (2017). Competencies, Organizational Citizenship Behavior, Person-Job Fit and Job Performance: Evidence from the Narcotics Control Bureau. International Journal of Advanced Biotechnology and Research (IJBR), 8(3), 279285.

Talebi, F., \& Abedini, M. (2016). Investigating the relationship between self-concept and job performance of managers. International Journal of Advanced and Applied Sciences, 3(1), 87-94.

Zhu, C., Wang, D., Cai, Y.H., \& Engels, N. (2013). What core competencies are related to teachers' innovative teaching? Asia-Pacific Journal of Teacher Education, 41(1), 9-27. 